\title{
Physicochemical properties of heat treated sille stone for ceramic industry
}

https://doi.org/10.1515/chem-2018-0122

received July 23, 2018; accepted September 15, 2018.

Abstract: Traditional building stones may be defined as the rocks continuously and commonly used throughout the history of a given town or region. Sille stone bears volcanic and andesitic features, which are unique to the Sille region (Konya) and its surroundings. Sille was a historical and cultural settlement in the Neolithic Age. The high silica content of Sille stone is an important building material due to its easy workability and durability properties. The Sille stone, which is generally used as a floor and wall covering, has many artifacts ranging from the Ottoman and Seljuk periods to the present day.

This work is aimed to determine the structural characteristics of Sille Stone, which still preserves its architectural value, and to reveal its potential of being used as an alternative material in the ceramic industry. For this purpose, chemical, physical and thermal properties of Sille Stone were determined in this investigation. The results indicate that the physical properties of Sille Stone are similar to industrial ceramic tiles, and it can be used as a ceramic material after a heat treatment or a surface coating application as this will prevent soluble salts from escaping that are contained in the porous structure and which can have harmful effects.

Keywords: Sille Stone; Physicochemical Properties; Ceramic; Characterization.

\section{Introduction}

The history of architecture and art are simultaneously related to the history of natural stones. Human beings have made use of natural stones for their social and cultural manifestations $[1,2]$. The use of natural stone in cultures

*Corresponding author: Çetin Öztürk, University of Necmettin Erbakan, Fine Arts Faculty, Traditional Turkish Arts Department, Ancient Ceramic Repair Program, Konya, Turkey, E-mail: cozturk@konya.edu.tr throughout history gives us insight to the members of those cultures [3]. Historical constructions are works that have lasted over the years, have filled lives, inspired later works, and which bear the traces of an individual civilization and civilizations $[4,5,6]$.

It is very important that the characteristics of the materials used in the historical buildings around the world are well-known and that this heritage bearing the past can be safely transferred to the future. The city of Konya which is located in Turkey was the capital of Anatolian Seljuk Empire in the 12th and 13th centuries and has hosted many civilizations during history. The city has many historical buildings and monuments which are part of prehistoric to medieval civilizations [4-7], including the Hittite monuments and distinctive Seljuk-Ottoman mosques, madrasahs, and caravansaries $[7,8]$.

Sille is a place located in the north of the Konya Province, $8 \mathrm{~km}$ from the city center, within the borders of Seljuk Municipality. The origin of settlement in Sille dates back to the Roman times. Many of the Byzantine churches and monasteries have still preserved their existence as a result of the carving of Sille stone, an andesitic-dacitic stone species formed as a consequence of volcanic mountains in the region [4]. Rapid cooling of the melted earth during volcanic activities that forms andesitedacite types of volcanic rock are composed of varied, glassy and unstable mineral phases [9]. These kinds of volcanic rocks are generally composed of plagioclase, quartz and igneous clasts [10]. Sille Stone is low in ash deposits, higher in porosity than andesites, and therefore, relatively easy to process. The capillary water absorption coefficient of Sille Stone was determined as $2.6-2.9 \mathrm{~kg} /$ $\mathrm{m}^{2} . \mathrm{h}$, which is higher than limestone, but lower than good-quality concrete. For this reason, it has been used safely for a long time as a building stone and a covering material. It is also a preferred stone in places where heat resistance is required. There is also no resource problem for Sille Stone [11].

Although some characterization studies were carried out on natural stones, very few studies were carried out on these types of stones relating to engineering materials 
[12-15]. This study focused on the characterization of physicochemical properties of Sille Stone and investigated the effect of heat on the microstructural and phase evolutions of Sille Stone to understand its thermal behavior.

\section{Experimental Studies}

Sille Stone from Sille, Konya were used in the experiments. Stones were cut into desired dimensions (e.g. core, rectangle prism and plate shapes) by cutting machines according to recommendations in ASTM D4543-08 for all relevant experimental studies. The series of measurements and characterization tests were conducted on Sille Stone samples after they were dried at $105^{\circ} \mathrm{C}$ overnight to remove any humidity in the pores and external surfaces.

\subsection{Petrographic Analysis of Sille Stone}

Thin sections of samples were prepared according to TS EN 12407 standards to identify the mineralogy and constituents of Sille Stone. Observations were carried out using a polarized light microscopy (Nikon, LV100POL, Japan) under environmental conditions of $18^{\circ} \mathrm{C}$ temperature and 35\% humidity. Laboratory petrographic examination procedures for stone materials according to the standard are described as follows. Thin sections in a square or rectangular shape of $0.5-1.0 \mathrm{~cm}$ in thickness were prepared by cutting them with a diamond-tip. Then, the surfaces of these sections were abraded and smoothed with coarse and fine sandpaper on a rotating metal disk and followed by the polishing of abrasive powder that was poured into a glass. The smooth and polished surface of the stone adhered to a glass called "lam" by a mixture of epoxy resin and hardener (4:1 mixing ratio). Finally, one side of the stone that adhered to the lam was polished and smoothed by the grinding disk until the sample thickness reached $0.02-0.03 \mathrm{~mm}$. If the thin section was thicker than the desired thickness, it was thinned further by the abrasion powders poured on the glass surface. The thinning process continued until the crystal size was clearly achieved. When the rock forming minerals were fully displayed in the microscope, the sample preparation was completed.

\subsection{Chemical and Mineralogical Analysis of Sille Stone}

X-ray fluorescence and diffraction analyses were performed on Sille Stone samples for chemical and mineralogical analysis, respectively. X-ray fluorescence spectroscopy (XRF; Rigaku, ZSX Primus II, Japan) was used to identify the chemical compositions. The sample preparation process was carried out by a grinding and pressing system. Sille stone chips were pulverized using a tungsten carbide grinding container and then a disc sample having a diameter of $20 \mathrm{~mm}$ was prepared using a manual hydraulic press with a capacity of $300 \mathrm{kN}$. A typical mineralogical phase analysis of Sille Stone, which collected from the field, was performed by an X-ray diffractometer (XRD; Bruker-D8 Advance, Germany), with $\mathrm{CuK \alpha}$ radiation, to determine the present crystalline phases of the sample.

\subsection{Determination of Physical Properties of Sille Stone}

Brunauer-Emmet-Teller (BET) approach on Quadrasorbevo 4 equipment (Quantachrome Instruments, USA) was used to determine porosity, surface area, pore volume, pore diameter, bulk density and apparent density. Adsorption isotherms were obtained from the adsorption of nitrogen gas $\left(\mathrm{N}_{2}\right)$ at $77 \mathrm{~K}$ in the liquid nitrogen environment to evaluate surface area, porosity and pore volume. Archimedes buoyancy technique was also applied to measure apparent porosity, water absorption, and bulk density. Dry weights, soaked weights and immersed weights in water were measured according to ASTM C2000 standard.

\subsection{Thermal analysis of Sille Stone}

The thermal properties of Sille Stone were analyzed through dilatometer, heating microscope, DTA-TG and thermal conductivity instruments. The coefficient of thermal expansion (CTE) for the stone samples was determined by dilatometric analysis. Specimens with rectangular shape test bars, in which $5 \times 5 \times 50 \pm 1 \mathrm{~mm}$, were used to comply with the size of the instrument. The experiment was executed between $25^{\circ} \mathrm{C}$ and $1100^{\circ} \mathrm{C}$ with a heating rate of $3^{\circ} \mathrm{C} / \mathrm{min}$ under $\mathrm{N}_{2}$ atmosphere using a dilatometer (Setaram Labsys 2000, France). To obtain volumetric changes during heating, crushed and milled stone grains $(<0.25 \mathrm{~mm})$ were compacted with a diameter 
of about $2 \mathrm{~mm}$ and a height of about $4 \mathrm{~mm}$. The volumetric changes of the compacted samples during heating at a rate of $50^{\circ} \mathrm{C} / \mathrm{min}$ until up to $1300^{\circ} \mathrm{C}$ were measured by a hot-stage microscope (Misura HSM 3M, Italy). Thermal analysis of the stone sample was carried out using a DTATG instrument. The thermal analysis involved heating the samples at a rate of $10^{\circ} \mathrm{C}$ min $^{-1}$ from ambient temperature to $1300^{\circ} \mathrm{C}$ and was performed by using a simultaneous thermal analyser (Netzsch STA 449 F3 Jupiter, Germany). The coefficient of thermal conductivity (CTC) of the stone sample with dimensions of $300 \times 300 \times 50 \mathrm{~mm}$ was made by the enclosed hot box method which is one of the methods specified in ASTM C1363-11. The general principle of this method is based on calculating the thermal conductivity of the material by a heat flux, created by the difference of heat energy that occurs between both surfaces of the material, passes through from the hot side to the cold side of the material. By measuring the heat flow over the material, the amount of heat passing through the unit area of the material is calculated. Measurements are made at steady-state air and surface temperatures. In order to prevent the heat loss from the edges of the sample during measurement, they are covered with heat-insulated materials so that the measurement is correct.

\subsection{Microstructural Observations of Sille Stone}

The microstructural observations were carried out by using a Scanning Electron Microscope (HITACHI SU 1510, Japan). The microstructural status of the Sille Stone and microstructural evaluation after heat treatments were observed by secondary electron imaging.

Ethical approval: The conducted research is not related to either human or animal use.

\section{Results and discussions}

\subsection{Petrographic (Microscopic) Structure of Sille Stone}

The petrographic examination of stones originates with onsite observation and finishes with a thin-section examination of a representative from the source area, the purpose of which is to obtain a reliable quality assessment of the material. The petrographic analysis of samples indicated that Sille Stone is a volcanic rock and its mineralogical composition consists of plagioclase,

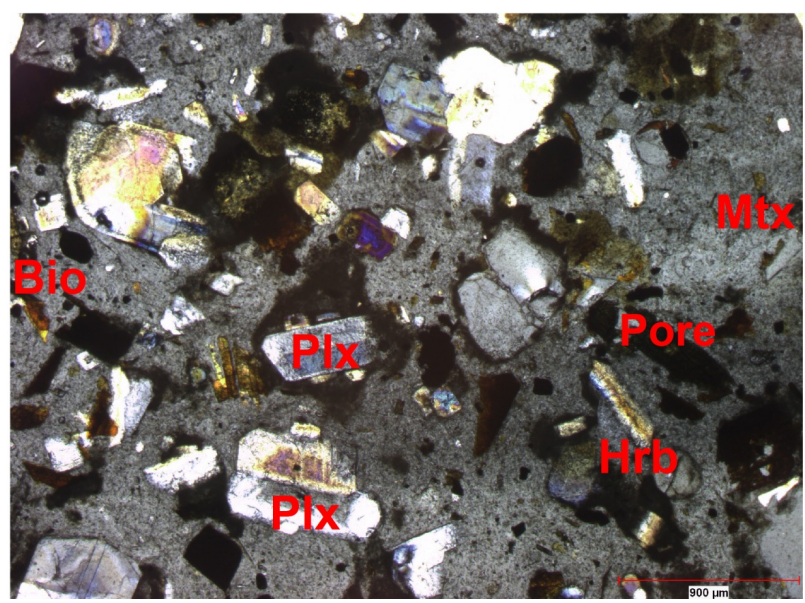

Figure 1: Petrographic analysis of a thin section of Sille stone.

hornblende and biotite minerals. Additionally, under a polarizing microscope, plagioclase microlites (Matrix) were detected as a binder (Figure 1). Moreover, undulatory extinction in thin sections of mineral grains was observed in the rock.

The chemical classification method commonly used in magmatic rocks and known as the total alkali-SiO (TAS) diagram was used to determine the rock class. The TAS diagram gives information to define the type of rocks depending on the amount of $\mathrm{SiO}_{2}$ and alkali oxides of natural stones [16,17]. The total amount of alkali and $\mathrm{SiO}_{2}$ contained in the Sille Stone were $7.52 \%$ and $64.50 \%$, respectively. The TAS diagram (Figure 2) shows that Sille Stone is located in the trachydacite region. As a result of the classification, it was determined that the Sille Stone was a trachydacite, which is subalkaline rock. Sille Stone, as in many volcanic rocks, is difficult or inadequately determined macroscopically, because the mineral constituents are generally fine-grained, whereas they can be clearly distinguished from plutonic rocks. The intrusive rocks exhibit a macroscopic planar and/or linear fabric by the arrangement of tabular shaped crystals (e.g. biotite and plagioclase). Plagioclases appear whitish dull to pale green [16]. This microscopic information conforms with that of Sille Stone.

Contrary this, the high biotite content (or presence) in the stones favors salt crystallization-induced decay because of the salts crystallizing between the biotite layers [18]. In their study, Zedef et al. [7] interpreted that the andesites of the Sille were susceptible to the effect of salt alteration. They claimed that if the pollutants, such as $\mathrm{SO}_{2}, \mathrm{NO}_{\mathrm{x}}, \mathrm{HNO}_{3}, \mathrm{O}_{3}$, and $\mathrm{H}_{2} \mathrm{SO}_{4}$, were transferred to rock surfaces by dry and wet deposition, salt crystallization would take place that would be responsible for the 


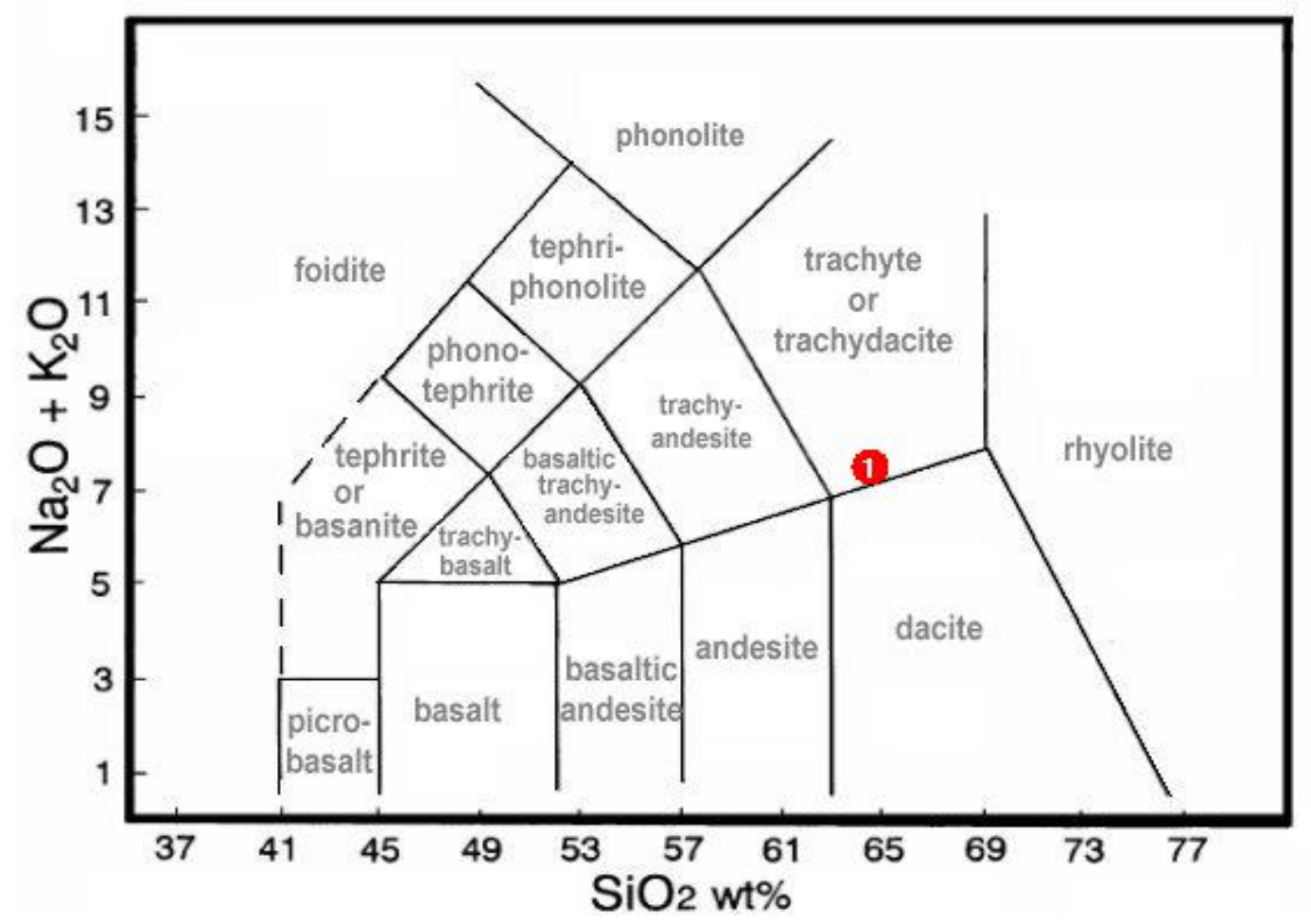

Figure 2: Chemical classification of Sille stone based on the total alkali-silica (TAS) diagram.

deterioration of the rocks. They also argued that the effect of salt crystallization would be more intense if the pollutants were deposited on cracked surfaces [7].

Some authors have studied the disintegration processes related to salt crystallization in the building stones. Ulusoy et al. [19] attributed the decay in architectural works made from volcanic (igneous) rocks to salt crystallization and capillary water elevation. Zedef et al. $[7,20,21]$ found that the effect of salt crystallization in the stone blocks constructed in the Konya region is most prevalent on the andesitic stone and that mineralogical, petrographic and physicomechanical properties of andesites are influenced by salt crystallization. It is necessary to restrict the utilization of Sille Stone in environments where salt is formed. Therefore, take some technological measures to prevent such salt formations is inevitable.

\subsection{Chemical and Mineralogical Structure of Sille Stone}

XRF analysis was carried out to determine the chemical composition of Sille Stone. Table 1 presents the XRF chemical results of the Sille Stone that was investigated.
The table shows that Sille Stone was enriched with $\mathrm{SiO}_{2}, \mathrm{Al}_{2} \mathrm{O}_{3}, \mathrm{CaO}, \mathrm{MgO}, \mathrm{Fe}_{2} \mathrm{O}_{3}$ and alkali oxides. Rocks of volcanic-origin are high in minerals that contain $\mathrm{SiO}_{2}$. The composition of the Sille Stone was found to have $65 \mathrm{wt}$. $\% \mathrm{SiO}_{2}$. The structure of Sille Stone was clearly confirmed by XRD analysis. The diffractogram, as shown in Figure 3, indicates a predominance of plagioclase peaks, the main mineral in stone, and followed by minor peaks of biotite and hornblende, which are the secondary phases. It is known that plagioclase is a mineral that occurs in alkali environments. This may show that the area Sille Stone was formed in an alkali environment and has a mineral composition of biotite, plagioclase, feldspar, and hornblende. The XRD patterns of the untreated Sille Stone and the heated, treated Sille Stone at $900^{\circ} \mathrm{C}$ and $1200^{\circ} \mathrm{C}$ are exhibited in Figure 3. For the heated stone treatment at $900^{\circ} \mathrm{C}$, the intensities of the diffraction peaks for biotite minerals were decreased. It was also found that the diffraction peaks belonging to hornblende and biotite completely disappeared as the stone received further heat treatment at a temperature of $1200^{\circ} \mathrm{C}$. Biotite and hornblende minerals were transformed into plagioclase at $1200^{\circ} \mathrm{C}$ and only the plagioclase phase remained stable. The transformation of the mineralogical structure of Sille Stone over $900^{\circ} \mathrm{C}$ will affect the physical and mechanical 
Table 1: Chemical composition of Sille stone.

\begin{tabular}{ll}
\hline Oxide & Weight (\%) \\
\hline $\mathrm{SiO}_{2}$ & 64.50 \\
$\mathrm{Al}_{2} \mathrm{O}_{3}$ & 16.40 \\
$\mathrm{~K}_{2} \mathrm{O}$ & 4.02 \\
$\mathrm{Na}_{2} \mathrm{O}$ & 3.50 \\
$\mathrm{CaO}$ & 3.97 \\
$\mathrm{MgO}$ & 1.85 \\
$\mathrm{Fe}_{2} \mathrm{O}_{3}$ & 3.24 \\
$\mathrm{MnO}$ & 0.11 \\
$\mathrm{TiO}_{2}$ & 0.46 \\
$\mathrm{P}_{2} \mathrm{O}_{5}$ & 0.19 \\
$\mathrm{SO}_{3}$ & 0.06 \\
$\mathrm{Cr}_{2} \mathrm{O}_{3}$ & 0.04 \\
$\mathrm{ZnO}$ & 0.01 \\
$\mathrm{SrO}_{\mathrm{ZrO}}$ & 0.08 \\
$\mathrm{BaO}_{2}$ & 0.02 \\
$\mathrm{LOI}$ & 0.12 \\
\hline
\end{tabular}

Table 2: Surface area and pore size analyses.

\begin{tabular}{ll}
\hline Surface Area $\left[\mathrm{m}^{2} / \mathrm{g}\right]$ & 230.0 \\
Pore Volume $\left[\mathrm{cm}^{3} / \mathrm{g}\right]$ & 0.072 \\
Average Diameter of Pores $[\mu \mathrm{m}]$ & 0.408 \\
Bulk Density [at $\left.0.50 \mathrm{psia} ; \mathrm{g} / \mathrm{cm}^{3}\right]$ & 2.092 \\
Apparent Density $\left[\mathrm{g} / \mathrm{cm}^{3}\right]$ & 2.465 \\
Porosity [\%] & 15.14 \\
\hline
\end{tabular}

properties of Sille Stone. The results derived from the XRF and XRD analysis were correlated with the results of the petrographic analysis.

\subsection{Physical Properties of Sille Stone}

The results of the surface area and pore size analysis are shown in Table 2. The specific surface area of Sille Stone was determined as $230 \mathrm{~m}^{2} / \mathrm{g}$. The BET analysis of Sille Stone indicated that it had a significant porosity (15\%) with an average diameter of pores $0.408 \mu \mathrm{m}$. The properties such as strength, thermal conductivity, and permeability were greatly influenced by pre-existing porosity within the Sille Sstone. Ghobadi and Babazadeh et al. [22] observed that building stones, which are loose and highly porous, could not withstand salt crystallization and lost almost half of their mass. The water absorption, bulk density and

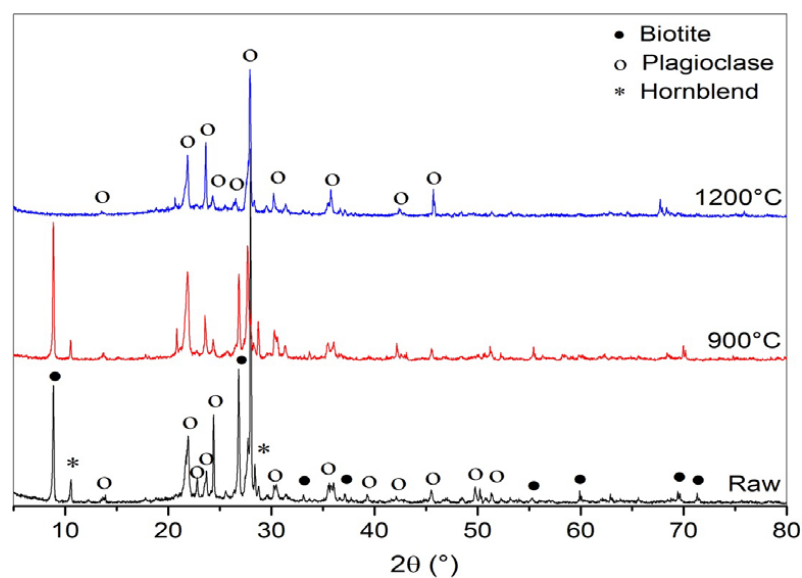

Figure 3: X-ray diffraction (XRD) analysis of Sille stone.

apparent porosity of Sille Stone samples were determined, by the Archimedes buoyancy technique, to be $11.02 \%, 2.21$ $\mathrm{g} / \mathrm{cm}^{3}, 18.95 \%$, respectively.

\subsection{Thermal Properties of Sille Stone}

Dilatometer analysis results measured from room temperature to $1100^{\circ} \mathrm{C}$ is exhibited in Figure 4. The thermal expansion coefficient (CTE) had a minimum value of $5.57 \times 10^{-60} \mathrm{C}^{-1}$ between $1000-1100^{\circ} \mathrm{C}$ and a maximum value of $11.98 \times 10^{-60} \mathrm{C}^{-1}$ between $100-200^{\circ} \mathrm{C}$. Figure 4 shows that the magnitude of the CTE decreased, after $500^{\circ} \mathrm{C}$, with a rising temperature of up to $1100^{\circ} \mathrm{C}$. CTE of ceramic bodies varies from 8 to $9 \times 10^{-60} \mathrm{C}^{-1}$ at low temperatures and to below $5 \times 10^{-60} \mathrm{C}^{-1}$ at high temperatures [23]. Subsequently, Sille Stone can be regarded as a ceramic body like tile. The softening and sintering temperature of Sille Stone is obtained by a heating microscope (Figure 5). The sample is heated up to $1300^{\circ} \mathrm{C}$ with a heating rate of $50^{\circ} \mathrm{C} \cdot \mathrm{min}^{-1}$. According to the results, it is found that softening and sintering begins at $1148^{\circ} \mathrm{C}$ and $1236^{\circ} \mathrm{C}$, respectively.

The reactions and weight loss generated during the heating of the Sille Stone determined by DTA and TGA are shown in Figure 6. Five endothermic peaks were obtained in the DTA curve at $130,460,577,1000$ and $1200^{\circ} \mathrm{C}$, which are attributed to the removal of moisture and impure volatile organics at $130^{\circ} \mathrm{C}$ and $460^{\circ} \mathrm{C}$, the alpha-beta quartz transition at $577^{\circ} \mathrm{C}$, structural breakdown of biotite to oxides at $1000^{\circ} \mathrm{C}$, and a mineral transformation to plagioclase at $1200^{\circ} \mathrm{C}$, respectively. However, it is recorded on the TGA curve that $1.40 \%$ of weight loss during heating which is totally completed at $600^{\circ} \mathrm{C}$ is due to the evaporation of moisture and oxidation of organic residues. Because of its porous structure, Sille Stone is composed of 


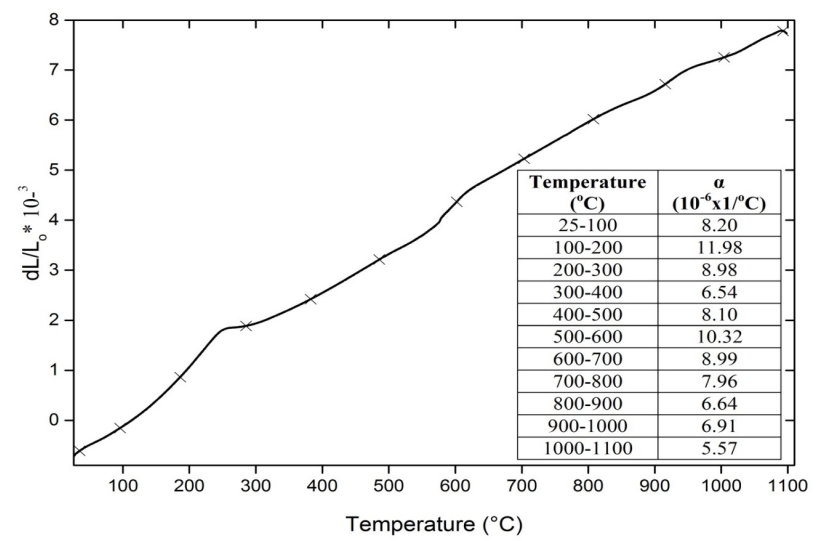

Figure 4: Dilatometer curve and CTE (coefficient of thermal expansion) of Sille stone.

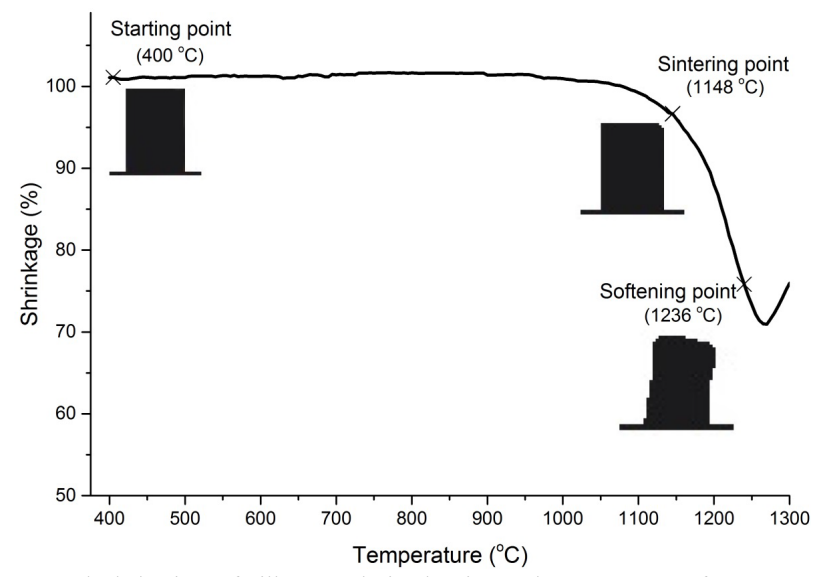

Figure 5: The behaviour of Sille stone during heating to the temperature of $1300^{\circ} \mathrm{C}$ at the rate of $50^{\circ} \mathrm{C} \mathrm{min}^{-1}$.

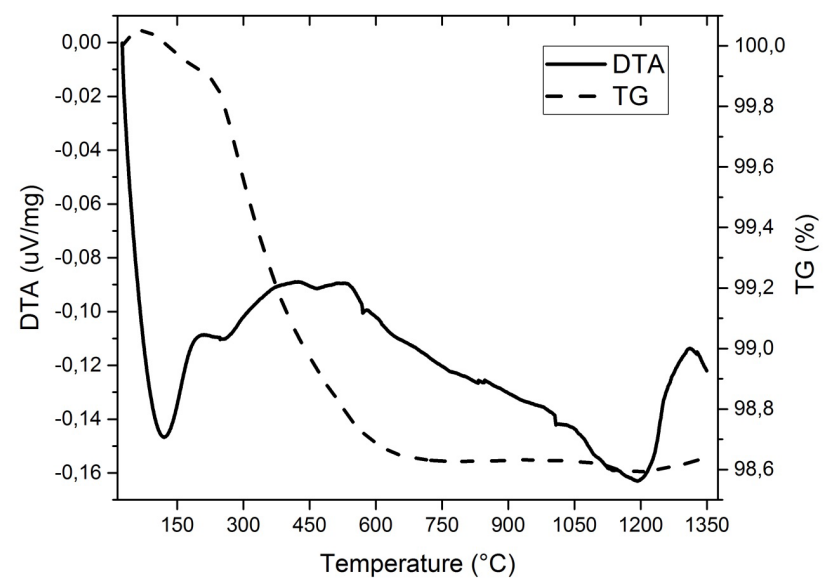

Figure 6: Simultaneous DTA-TGA analysis of Sille stone. oxide-based phases and air. CTC of Sille Stone measured by the hot box method was found to be $1.35 \mathrm{~W} / \mathrm{m}$.K at room temperature.

\subsection{Microstructural Change of Sille Stone Under the Heating Effect}

The scanning electron microscopy micrographs of Sille Stone, as seen in Figures 7, 8 and 9, indicate that the structure was composed of granular and fibrous phases and also porosity. While the granular structure contains plagioclase and hornblende minerals, Energy dispersive spectrometer measurements from fibrous structure observed in SEM was found to be biotite according to elemental compositions. The SEM analysis of the raw Sille Stone in Figure 7, showed biotite fiber bundles, between 0.21-5.08 $\mu \mathrm{m}$ width and 14-47 $\mu \mathrm{m}$ in length, and typically with an aspect ratio of 25:1. The average fiber diameter is $1.05 \mu \mathrm{m}$. Moreover, the salt presence was observed like efflorescence over the surface of the matrix and some fibrous biotite, in the electron microscopy micrographs. SEM micrographs of heat treated Sille Stone at $900^{\circ} \mathrm{C}$ is displayed in Figure 8. The salts like efflorescence over the surface of the matrix and some fibrous biotite have completely disappeared. The deformation of the biotite fibers has started. Moreover, the crystals of hornblende and biotite completely disappeared in the matrix as the stone was heated to $1200^{\circ} \mathrm{C}$ (Figure 9). As mentioned above, these minerals were transformed into plagioclase according to XRD results at $1200^{\circ} \mathrm{C}$, and the only matrix of plagioclase that remained in the microstructure is seen in Figure 9.

\section{Conclusions}

Analysis indicates that the Sille Stone consists of plagioclase, hornblende and biotite minerals which are a type of rock of volcanic-origin with high $\mathrm{SiO}_{2}$-containing (65 wt. \%); it was found to be a trachydacite according to classification in the TAS diagram. The XRD analysis of the Sille Stone indicates that biotite and hornblende minerals transform into plagioclase by a heat treatment of $1200^{\circ} \mathrm{C}$. Its apparent porosity, bulk density, and water absorption values were $18.95 \%, 2.210 \mathrm{~g} / \mathrm{cm}^{3}$ and $11.02 \%$, respectively. CTE has a minimum value of $5.57 \times 10^{-60} \mathrm{C}^{-1}$ between 1000 $1100^{\circ} \mathrm{C}$ and has a maximum value of $11.98 \times 10^{-6} \mathrm{C}^{-1}$ between $100-200^{\circ} \mathrm{C}$. CTC of Sille Stone is found to be $1.35 \mathrm{~W} / \mathrm{m} . \mathrm{K}$ at room temperature. 

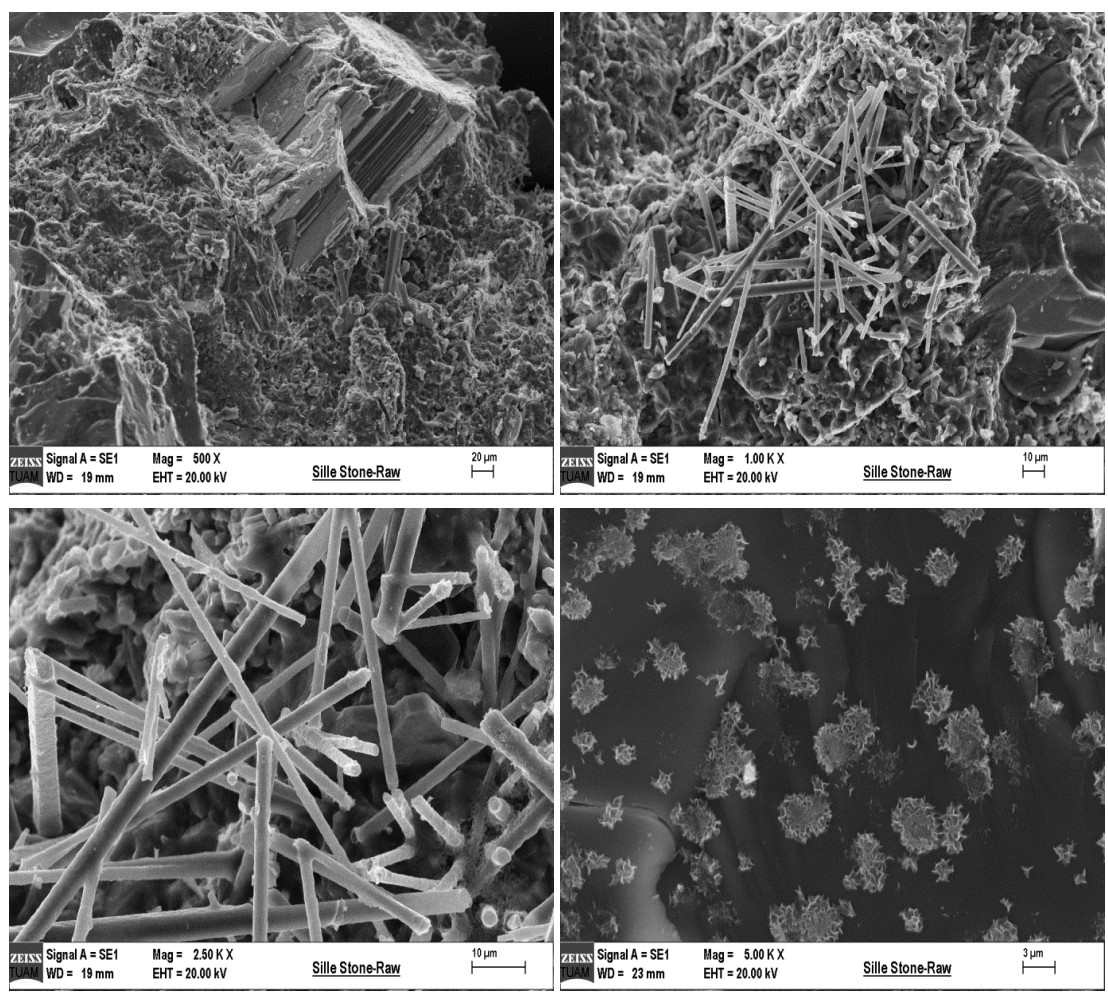

Figure 7: SEM micrographs of raw Sille stone.
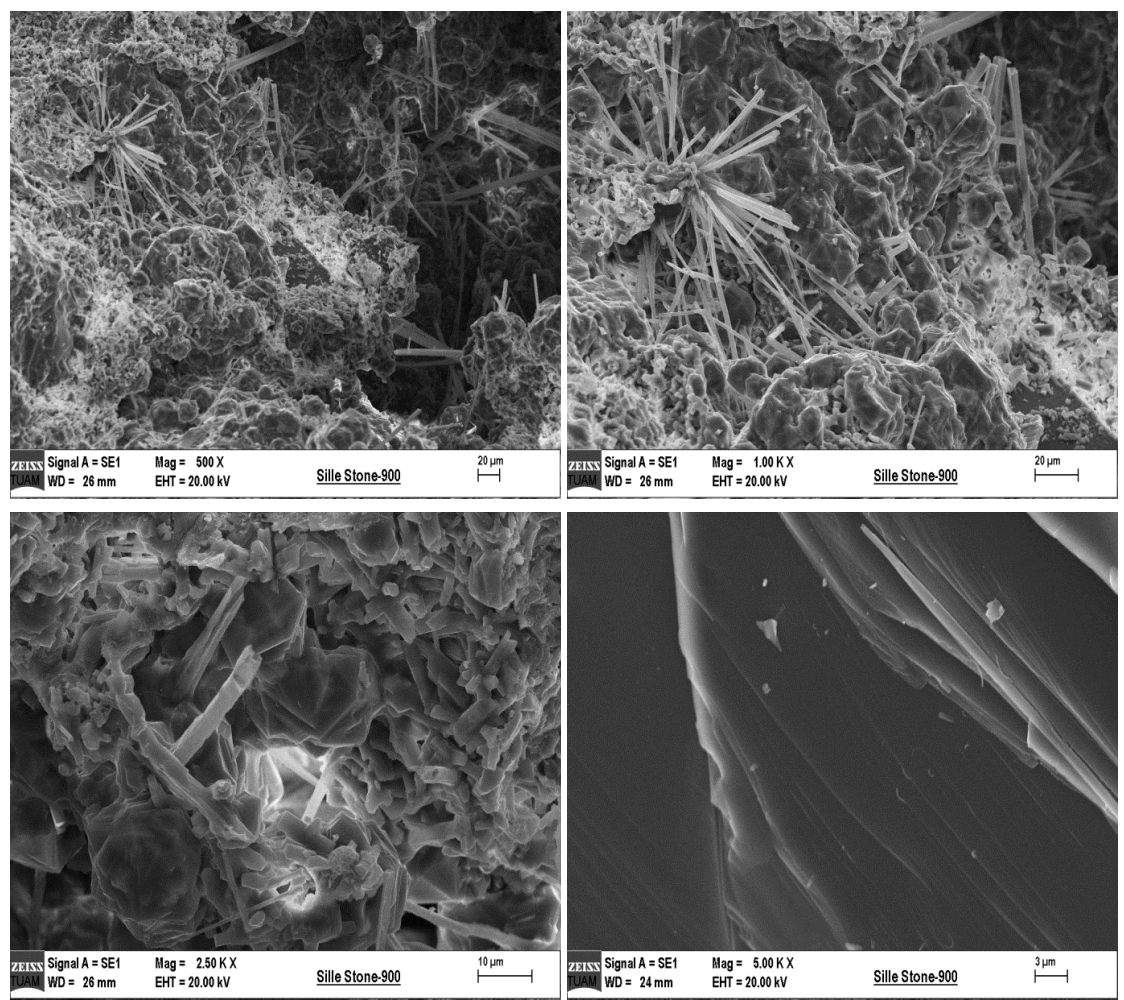

Figure 8: SEM micrographs of heat treated-Sille stone at $900^{\circ} \mathrm{C}$. 

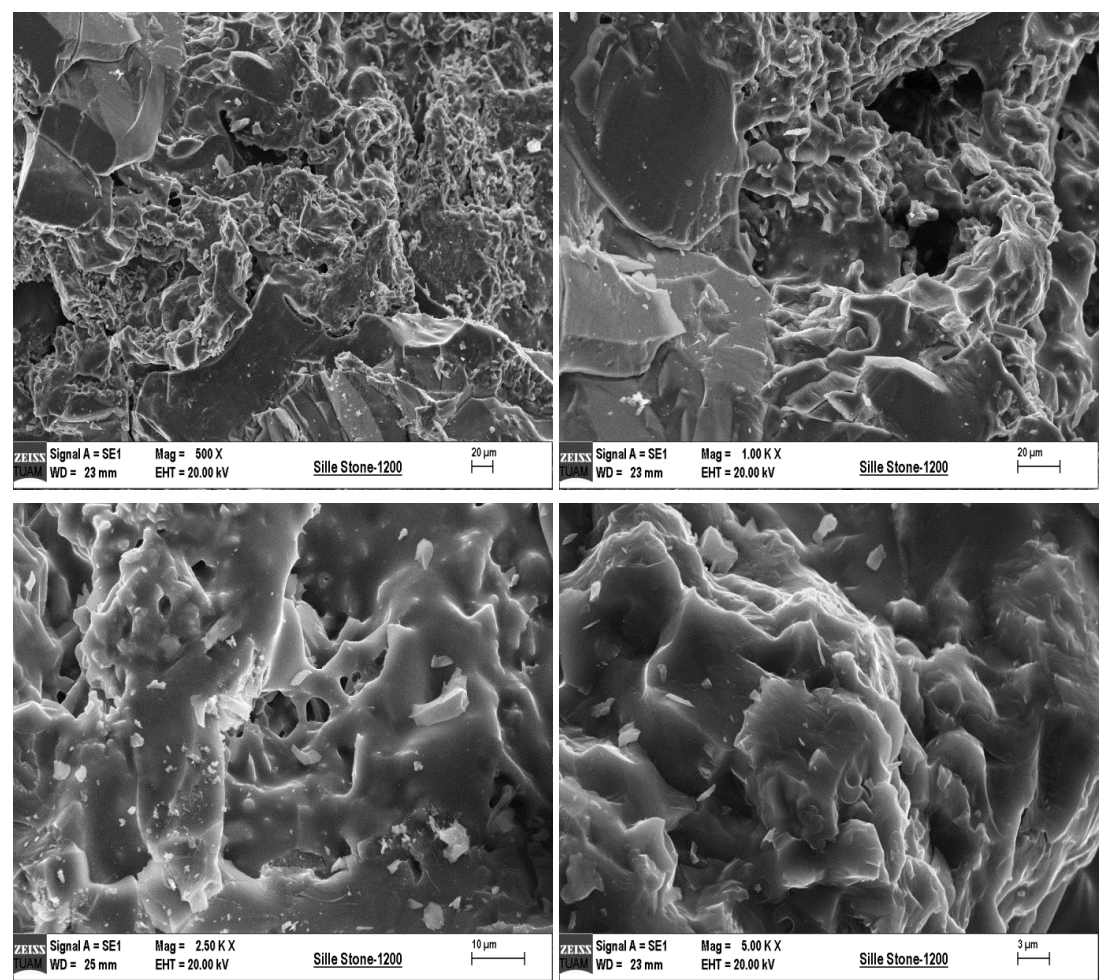

Figure 9: SEM micrographs of heat treated-Sille stone at $1200^{\circ} \mathrm{C}$.

In heat microscope measurements, the softening and sintering temperatures were recorded as 1148 and $1236^{\circ} \mathrm{C}$, respectively. The results of the DTA-TGA analysis confirmed the mineral transformation to plagioclase at $1200^{\circ} \mathrm{C}$. The salt presence was observed as efflorescence over the surface of the matrix and some fibrous biotite, in the untreated Sille Stone by electron microscopy analysis. The use of Sille Stone is limited in environments where salt is formed. Therefore, take some technological measures to prevent such salt formations is inevitable.

Even though the physical properties of Sille Stone is similar to industrial ceramic tiles, and they can be used as a ceramic material after a heat treatment or a surface coating application, there are harmful effects of the soluble salts that exist in the Sille Stone's porous structure.

Conflict of interest: Authors declare no conflict of interest.

\section{References}

[1] Farrelly L., The Fundamentals of Architecture, Switzerland, AVA Publishing SA, 58-86, 2007.
[2] Bozkurt N., and Taşkin V., Design of Self Compacting Lightweight Concrete Using Acidic Pumice with Different Powder Materials, Acta Physica Polonica A, 2007, 132, 3.

[3] Akman M.S., Yapı Malzemelerinin Tarihsel Gelişimi, Türkiye Mühendislik Haberleri, 2003, 426, 30-36.

[4] Saydan M., Determination of some mechanical, mineralogical, geo-chemical and pozzolanic properties of Sille rocks used in historical building in Konya region, M.Sc Thesis, Selçuk University, 2015.

[5] Çetin B, Oner F.and Akkurt İ., Determination of Natural Radioactivity and Associated Radiological Hazard in Excavation Field in Turkey (Oluz Höyük), Acta Physica Polonica A, 2016, 130, 1.

[6] Kulali F., Akkurt I., Investigation of Radon Concentrations in Pamukkale-Turkey, Acta Physica Polonica A, 2015, 128, 2-B.

[7] Zedef V., Unal M., Effect of Salt Crystallization on the Building Stones Used in Konya, Central Turkey, Int. J. Econ. and Environ. Geol. 2010, 1(1), 51-52.

[8] Fener M., Ince I., Effects of the freeze-thaw (F-T) cycle on the andesitic rocks (Sille-Konya/Turkey) used in construction building, Journal of African Earth Sciences, 2015, 109, 96-106.

[9] Howe T.M., Lindsay J.M., Shane P., Evolution of young andesitic-dacitic magmatic systems beneath Dominica, Lesser Antilles, Journal of Volcanology and Geothermal Research, 2015, 297, 69-88.

[10] Bond G.C., A Late Paleozoic Volcanic Arc in the Eastern Alaska Range, Alaska, The Journal of Geology, 1973, 81(5), 557-575.

[11] Kazancı N., Gurbuz A., Natural Stones Qualified as Geological Heritage in Turkey, Geological Bulletin of Turkey, 2014, 57, 1. 
[12] Kamacı Z., Özer P., Engineering Properties of Eğirdir-Kızıldağ Harzburgitic Peridotites in Southwestern Turkey, International Journal of Computational and Experimental Science and Engineering, 2018, 4(2), 14-22.

[13] Kilincarslan Ş., Davraz M., Akça M., The effect of pumice as aggregate on the mechanical and thermal properties of foam concrete, Arabian Journal of Geosciences, 2018, 11, 289.

[14] Divband B., Rashidi M. R., Khatamian M., Kazemi Eslamian G. R., Gharehaghaji N., Dabaghi Tabriz F., Linde Type A and nano magnetite/NaA zeolites: cytotoxicity and doxorubicin loading efficiency, Open Chemistry, 2018, 16(1), 21-28.

[15] Hu Q., Zeng W.A., Li F., Huang Y., Gu S., Cai H., Zeng M., Li Q., Tan L., Effect of Nano Zeolite on the Transformation of Cadmium Speciation and Its Uptake by Tobacco in Cadmiumcontaminated Soil, Open Chemistry, 2018, 16(1), 667-673.

[16] Siegesmund S. and Snethlage R., Stone in Architecture: Properties, Durability, Berlin: Springer, 2011.

[17] Le Bas M.J., Le Maitre T.W., Streckeisen A., Zanettin B., A chemical classification of volcanic rocks based on the total alkali-silica diagram. Journal of Petrology, 1986, 27, 745-750.

[18] López-Arce P., Varas-Muriel M.J., Fernández-Revuelta B., Álvarez de Buergo M., Fort R. \& Perez-Soba C., Artificial weathering of Spanish granites subjected to salt crystallization tests: surface roughness quantification, Catena, 2010, 83, 170-185.

[19] Ulusoy M., Different igneous masonry blocks and salt crystal weathering rates in the architecture of historical city of Konya, Building and Environment, 2007, 42, 3014-24.

[20] Zedef V., Kocak K., Doyen A., Ozsen H., Kekec B., Effect of salt crystallization on stones of historical buildings and monuments, Konya, Central Turkey, Building and Environment, 2007, 42, 1453-1457.

[21] Zedef V., Ağaçayak T., Söğüt A.R., Koçak K., Dimension stones used in Central Anatolia: Some of their geological and mechanical properties. Sci Res Essays, 2011, 6(13), 2655-2659.

[22] Ghobadi M.H., Babazadeh R., Experimental Studies on the effects of cyclic freezing-thawing, salt crystallization, and thermal shock on the physical and mechanical characteristics of selected sandstones. Rock Mechanics and Rock Engineering, 2014, 48(3), 1001-16.

[23] Eppler R.A and Eppler D.R., Glazes and Glass Coating, American Ceramic Society, Westerville, Ohio, 2000. 